\title{
The Correlation between HPV Infection and Cell Proliferative Activity in Uterine Cervical Adenocarcinoma
}

\author{
Kazuo Shikano, Hironobu Sasano*, Kiyoshi Ito, \\ Nobuyoshi Ozawa, Toru Tase, Shinji Sato and Akira \\ YAJIMA \\ Department of Obstetrics and Gynecology, and * Department \\ of Pathology, Tohoku University School of Medicine, Sendai \\ 980
}

Shikano, K., Sasano, H., Ito, K., Ozawa, N., Tase, T., Sato, S. and Yajima, A. The Correlation between HPV Infection and Cell Proliferative Activity in Uterine Cervical Adenocarcinoma. Tohoku J. Exp. Med., 1993, 169 (4), 279-288 - To investigate the correlation between human papillomavirus (HPV) infection and cell proliferative activity in uterine cervical adenocarcinoma, in situ hybridization of HPV DNA and immunostaining of proliferative cell nuclear antigen (PCNA) were performed on serial sections of the carcinoma. HPV 16 and 18 DNA was detected in 10 of 33 cases of cervical adenocarcinoma and adenocarcinoma in situ. PCNA was detected in 30 cases. In all $10 \mathrm{HPV}$-positive cases, PCNA was also demonstrated, and the number of PCNA-positive cells tended to be higher than that in HPV-negative cases. With $1: 1$ correlation between HPV and PCNA on the nuclei, the coincidence rate was $72 \%(p<0.01)$. These results indicate that HPVs play a role in cell proliferation. - uterine cervical adenocarcinoma; HPV; PCNA; in situ hybridization

The close association between human papillomavirus (HPV) and uterine cervical squamous cell carcinoma suggests a role for the virus in the development of this tumor (Yoshikawa et al. 1985; Ostrow et al. 1987; Walker et al. 1989). Cervical adenocarcinoma is increasing in incidence, particularly in women under the age of 25 years (Chilvers et al. 1987). A number of investigators have reported the presence of HPV in cervical adenocarcinoma tissue (Tase et al. 1988a, b, 1989; Farnsworth et al. 1989; Gordon et al. 1989; Nielsen 1990).

A number of reports have indicated that some of the open reading frames of HPV 16 code for transforming genes (Banks et al. 1990). It has been postulated that cells infected with HPV behave as though stimulated by a non-specific mitogen and that in a semipermissible epithelium, many cells remain in a prolonged S or G2 phase (Reid et al. 1982). Hughes et al. recently demonstrated by flow cytometry that HPV antigen-positive specimens were found to contain more dividing cells than did negative specimens (Hughes et al. 1989). Therefore, it has

Received February 6, 1992; revision accepted for publication February 11, 1993. 
been hypothesized that HPV infection resulted in stimulated cell division. However, to the best of our knowledge no detailed studies of the correlation between cell proliferation and HPV infection at the cellular level have been reported in human neoplasm.

Recently, immunohistochemical analysis of cell cycle-related antigens has contributed greatly to assessing cell kinetics in tissue sections. One of these antigens, proliferative cell nuclear antigen (PCNA), also known as cyclin, is a 36 kDa nuclear protein (Takasaki et al. 1981; Mathews et al. 1984). This protein is an auxiliary protein of DNA polymerase delta and its expression is correlated with the late G1 and S-phase of the cell cycle (Takasaki et al. 1981; Mathews et al. 1984).

PCNA immunostaining can demonstrate cells that are in the proliferative stage in tissue sections. Therefore, in this investigation, we have studied HPV infection in cervical adenocarcinoma by in situ hybridization. In order to correlate HPV infection with cell proliferation, PCNA immunostaining was conducted in serial sections of the specimen in which in situ hybridization was performed.

\section{Materials and Methods}

\section{Materials}

$10 \%$ formalin-fixed and paraffin-embedded blocks of 33 cases of cervical adenocarcinoma and 6 cases of adenocarcinoma in situ were retrieved from the surgical pathology files of the Department of Pathology, Tohoku University; Miyagi Cancer Society; and NTT Tohoku Hospital, all located in Sendai. They were routinely processed in surgical pathology laboratories.

\section{In situ hybridization}

The tissue blocks were cut into $5-\mu \mathrm{m}$ sections. They were then placed on 3aminopropyltriethoxysilane (AES)-treated glass slides (Tourtellotte et al. 1987). The slides were air-dried at $37^{\circ} \mathrm{C}$ for $18 \mathrm{hr}$ and stored at $4^{\circ} \mathrm{C}$.

Prior to deparaffinization, glass slides were baked at $60^{\circ} \mathrm{C}$ for $2 \mathrm{hr}$.

In situ hybridization employing biotin-labeled DNA probes

In situ hybridization was performed employing a ViraType in situ kit (Life Technologies, Inc., Gaithersburg, MD, USA) with some modifications. The biotinylated DNA probes employed in this study consisted of three different mixture types (HPV6/11, 16/18, $31 / 33 / 35$ ). The positive control probe was hybridized with human genomic DNA, and the negative control with PBR 322 DNA. The procedures were as follows:

Sections were deparaffinized in two changes of fresh xylene for 5 min each and dehydrated in 2 changes of $100 \%$ ethanol for 5 min each at $23^{\circ} \mathrm{C}$. The deparaffinized sections were then incubated with a digestion solution containing $\mathrm{HCl}$ and proteolytic enzyme for 15 min at $37^{\circ} \mathrm{C}$, washed in the buffer 1 (Tris-buffered saline) for one minute, and dehydrated in $95 \%$, absolute ethanol for one minute. The sections were incubated with $40 \mu$ l of DNA probe solution in the kit, covered with clean glass cover slips, heated at $90^{\circ} \mathrm{C}$ for $5 \mathrm{~min}$ on a hot metal plate, and hybridized at $37^{\circ} \mathrm{C}$ for $18 \mathrm{hr}$.

The cover slips were removed by immersing the slides in the buffer 2 solution (Trisbuffered saline, bovine serum albumin). The sections were then washed three times with 
the buffer 2 at $37^{\circ} \mathrm{C}$ for 3 min each. The sections were covered with the detection reagent in the kit (streptavidin-alkali phosphate conjugate) and incubated in a humidified box for $20 \mathrm{~min}$ at $37^{\circ} \mathrm{C}$. The sections were washed three times with the buffer 3 (Tris-buffered saline) for $3 \mathrm{~min}$ each and then incubated with substrate solution (5-bromo-4-chloro-3indolyl phosphate, nitroblue tetrazolium) at $37^{\circ} \mathrm{C}$ for $30 \mathrm{~min}$. They were then washed in three changes of distilled water. The sections were counterstained, rinsed in distilled water and dehydrated in $95 \%$ and $100 \%$ ethanol. They were then immersed in xylene and mounted with cover slips.

To investigate the sensitivity of our methods, formalin-fixed, paraffin-embedded sections of cultured cell lines deriving from cervical carcinoma (Hela, Caski and $\mathrm{SiHa}$ ) were made. In situ hybridization was performed with the ViraType in situ method. We could detect HPV type $16 / 18$ in the Hela and Caski cases, which contained more than 10 copies per cell, but not in the SiHa cases, which contained less than 10 copies.

\section{In situ hybridization with a digoxigenin-labeled DNA probe}

HPV DNA (type 16,18) was labeled with digoxigenin according to the procedure of the DNA labeling kit (Boehringer Mannheim, Germany). DNA labeling was performed by incorporating a nucleotide analog (digoxigenin-11-dUTP) into the DNA by the random primered labeling technique. In situ hybridization was mainly performed based on the method of Heiles, with several modifications (Heiles et al. 1988)

Briefly, tissue sections were deparaffinized in two changes of xylene for 10 min each, dehydrated in graded ethanol $(95 \%$ and $100 \%$ for $5 \mathrm{~min}$ each), and washed twice in PBS containing $5 \mathrm{mM} \mathrm{MgCl}{ }_{2}$ at $23^{\circ} \mathrm{C}$ for $10 \mathrm{~min}$ each. The sections were incubated in $0.2 \mathrm{~N} \mathrm{HCl}$ for $20 \mathrm{~min}$ at $23^{\circ} \mathrm{C}$, then washed twice in $2 \times \mathrm{SSC}$ containing $5 \mathrm{mM}$ EDTA for $10 \mathrm{~min}$ at $50^{\circ} \mathrm{C}$, and treated with $50 \mu \mathrm{g} / \mathrm{ml}$ of proteinase $\mathrm{K}$ for $15 \mathrm{~min}$ at $37^{\circ} \mathrm{C}$. They were washed with $0.2 \%$ glycine in $\mathrm{PBS}$ for $10 \mathrm{~min}$ at $23^{\circ} \mathrm{C}$, then postfixed with $4 \%$ paraformaldehyde for 10 min. The sections were washed twice in PBS containing $5 \mathrm{mM} \mathrm{MgCl}$ for $10 \mathrm{~min}$ at $23^{\circ} \mathrm{C}$ and were rinsed in distilled water. The sections were incubated in $100 \mu \mathrm{g} / \mathrm{ml}$ of RNAse for $30 \mathrm{~min}$ at $37^{\circ} \mathrm{C}$, washed three times in $2 \times \mathrm{SSC}$ for $5 \mathrm{~min}$ at $23^{\circ} \mathrm{C}$, rinsed in distilled water, and dehydrated in $70 \%, 95 \%$, and $100 \%$ ethanol.

Digoxigenin-labeled HPV DNA probes were mixed with the hybridization solution $(6 \times$ SSC, $45 \%$ formamide, $5 \times$ Denhardt's solution, $100 \mu \mathrm{g} / \mathrm{ml}$ salmon sperm DNA, $10 \%$ Dextran sulfate), and were denatured at $100^{\circ} \mathrm{C}$ for $10 \mathrm{~min}$. They were then cooled on ice for $10 \mathrm{~min}$. The hybridization solution was incubated with the sections and a probe with approximately $5 \mathrm{ng}$ of digoxigenin-labeled HPV DNA was placed on a slide. The reacted sections were covered with siliconized glass cover slips, heated at $90^{\circ} \mathrm{C}$ for $5 \mathrm{~min}$, and cooled on ice for 10 min. They were then hybridized at $37^{\circ} \mathrm{C}$ for $18 \mathrm{hr}$.

The sections were subsequently washed twice with $6 \times \mathrm{SSC}$ containing $45 \%$ formamide at $37^{\circ} \mathrm{C}$ for $15 \mathrm{~min}$ each, twice with $2 \times \mathrm{SSC}$ at $23^{\circ} \mathrm{C}$ for $5 \mathrm{~min}$, then twice with $0.5 \times \mathrm{SSC}$ at $50^{\circ} \mathrm{C}$ for $15 \mathrm{~min}$.

The sections were washed in the buffer I ( $100 \mathrm{mM}$ Tris-HCl, $150 \mathrm{mM} \mathrm{NaCl}, \mathrm{pH} 7.5)$ for one minute, incubated in the buffer I containing $2 \%$ normal sheep serum for 30 min, and briefly washed in the buffer I. The sections were then incubated with sheep antidigoxigenin polyclonal antibody conjugated with alkali phosphatase at $1: 500$ dilution for $30 \mathrm{~min}$ at $23^{\circ} \mathrm{C}$. They were washed twice in the buffer I for $15 \mathrm{~min}$, equilibrated with the buffer II (100mM Tris-HCl, $100 \mathrm{mM} \mathrm{NaCl}, 50 \mathrm{mM} \mathrm{MgCl}_{2}, \mathrm{pH} \mathrm{9.5)} \mathrm{for} 2 \mathrm{~min}$, and incubated with color solution (nitroblue tetrazolium, 5-bromo-4-shloro-3-indolyl phosphate) in a dark room at $23^{\circ} \mathrm{C}$ for 15 to $30 \mathrm{~min}$. They were washed in TE buffer and then in distilled water. The sections wer counterstained with nuclear fast red, rinsed in distilled water and dehydrated by grading in ethanol and xylene. The sections were then mounted with mounting medium.

The digoxigenin-labeled HPV DNA probes could detect 1-0.3 pg of homologous DNA on dot blot hybridization. By comparing the dot blot with the control probe (pBR328) in the 
kit, the concentration of the digoxigenin-labeled probes was estimated before they were used for in situ hybridization.

Immunohistochemistry of PCNA

Serial sections were cut in 33 of 39 cases. PCNA was immunostained on the adjacent serial sections in which in situ hybridization was performed.

Tissue sections were deparaffinized and immersed in methanol with $0.3 \%$ hydrogen peroxide for $30 \mathrm{~min}$ to block endogenous peroxidase activity. They were rinsed three times in distilled water, washed in three changes of $0.01 \mathrm{M}$ PBS for 5 min each, and treated with $1 \%$ normal rat serum for $30 \mathrm{~min}$ at $23^{\circ} \mathrm{C}$. After washing with PBS, sections were incubated with anti-PCNA monoclonal antibody PC10 (Novocastra Labs., Newcastle, England), diluted at $1: 200$ at $4^{\circ} \mathrm{C}$ for $18 \mathrm{hr}$ in a humidified chamber.

After washing in three changes of PBS for 5 min each, the sections were incubated with biotinylated anti-mouse IgG antibody and peroxidase-conjugated streptavidin for $30 \mathrm{~min}$ each at $23^{\circ} \mathrm{C}$ in a humidified chamber with washing in PBS between incubations. A final wash was followed by immersion in a solution of diaminobenzidine. The sections were counterstained with $1 \%$ methyl green and mounted.

\section{Results}

\section{In situ hybridization}

In 14 of 39 cases of cervical adenocarcinoma ( $36 \%$ ), HPV16 or 18 DNA were detected by in situ hybridization. All of the cases that were positive on ViraType in situ were also positive with the digoxigenin method in these experiments. HPV18 was detected in 7 out of 30 invasive adenocarcinoma lesions, in two out of three cases of adenosquamous carcinoma, and in two out of 6 cases of adenocarcinoma in situ. In contrast, only 3 cases of invasive adenocarcinoma were positive for HPV16 (Table 1).

In both the ViraType in situ and digoxigenin-labeled probe positive cases, hybridization signals were observed as blue-purple granules on the nuclei of the carcinoma cells (Fig. 1.) Hybridization signals were not present in the nuclei of normal endocervical glands and squamous epithelium.

Hybridization signals were usually observed as one to several spots on the nuclei.

\section{Immunohistochemistry of PCNA}

In the 33 examined cases (25 adenocarcinoma, 3 adenosquamous carcinoma, and 5 adenocarcinoma in situ), PCNA was positive in 30 . Among these cases, hybridization signals of HPV were observed in 10. PCNA immunoreactivity was

TABLE 1. Detection of HPV DNA in uterine cervical adenocarcinoma

\begin{tabular}{lccc}
\hline \multicolumn{1}{c}{ Histological diagnosis } & Number of cases & HPV-16 & HPV-18 \\
\hline Adenocarcinoma & 30 & 3 & 7 \\
Adenosquamous carcinoma & 3 & 0 & 2 \\
Adenocarcinoma in situ & 6 & 0 & 2 \\
\hline
\end{tabular}




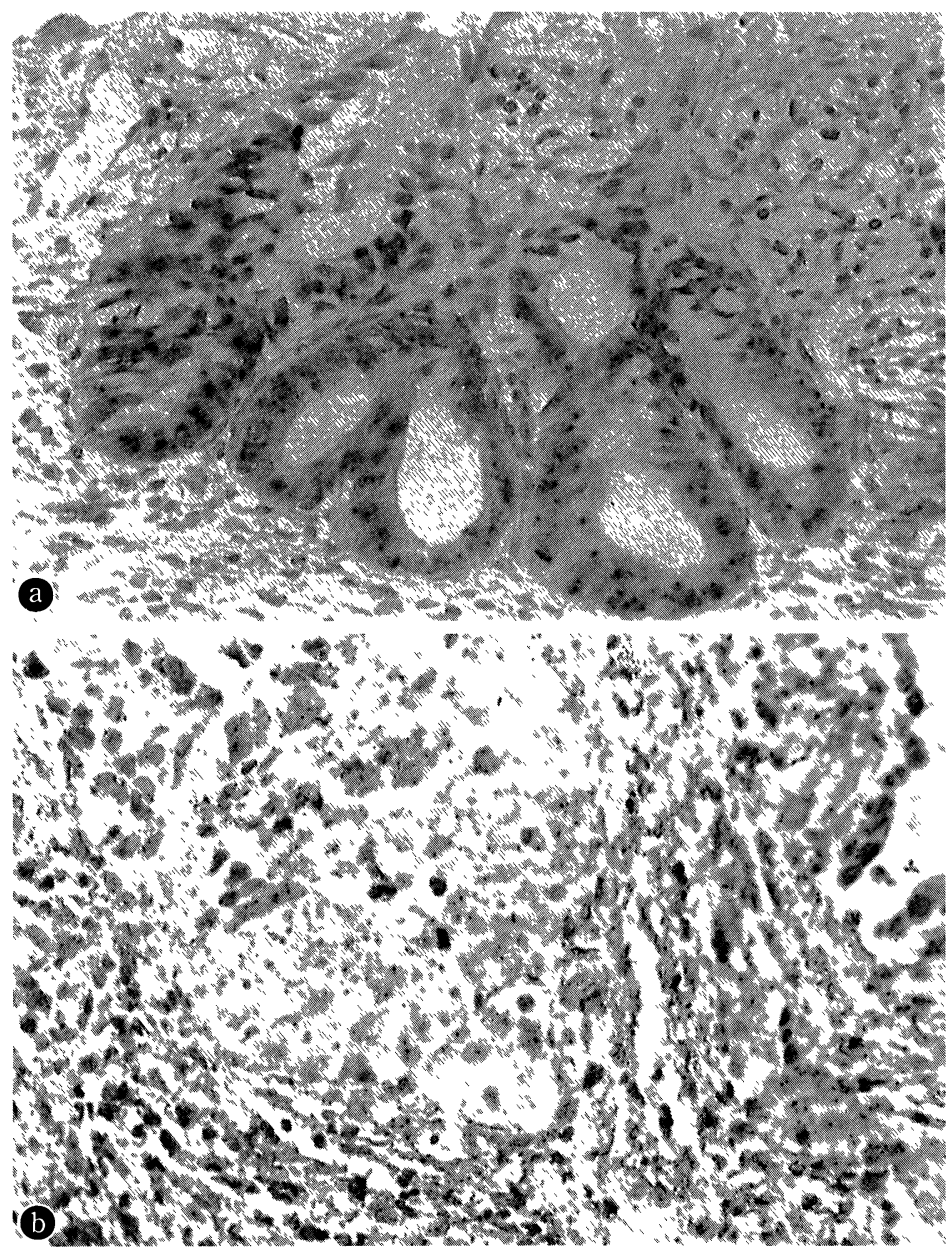

Fig. 1. HPV-positive cases by ISH.

a) A section hybridized with an HPV 16/18 DNA probe by the ViraType in situ method; b) A section hybridized with an HPV-18 DNA probe labeled with digoxigenin.

demonstrated only in the nuclei (Fig. 2).

\section{Correlation between PCNA and HPV-positive cells}

In all $10 \mathrm{HPV}$-positive cases, PCNA was also detected (Table 2).

The number of PCNA-positive cancer cells was evaluated in 10 cases positive for HPV. There was a tendency for the number of PCNA-positive nuclei to be higher in the HPV-positive cases (Table 3).

The number of HPV-positive nuclei and PCNA in 10 high-power fields $(400 \times)$ was compared in the HPV-positive cases. In the same examined fields, the number of HPV-positive nuclei tended to correlate with that of the PCNA- 


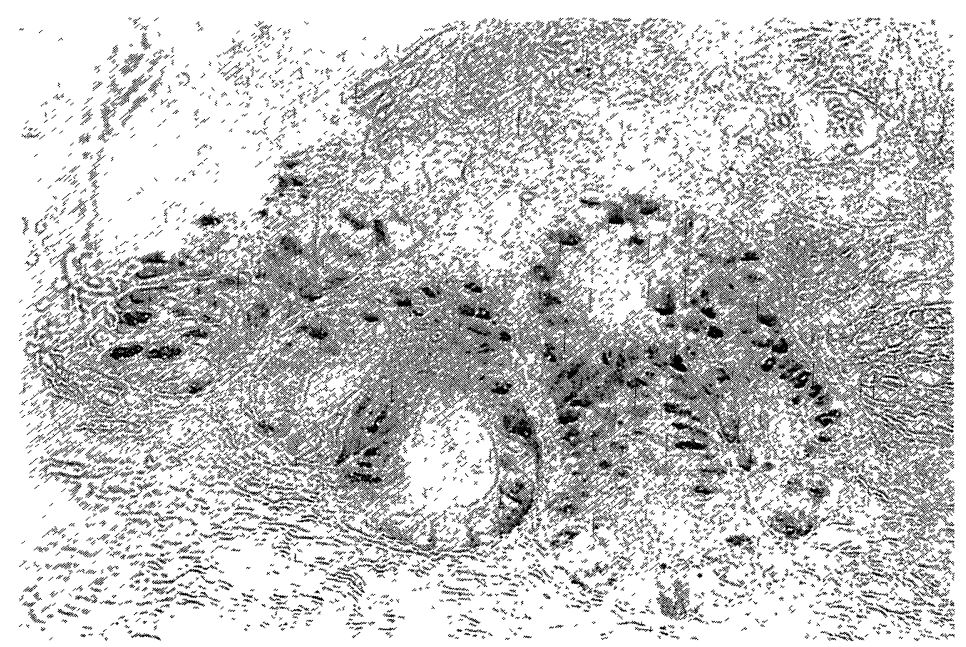

Fig. 2. A positive case of PCNA, the same case and the same field as in Fig. 1a.

TABLE 2. Correlation between HPV and PCNA in serial sections

\begin{tabular}{lccc}
\hline & PCNA positive & PCNA negative & Total \\
\hline HPV positive & 10 & 0 & 10 \\
HPV negative & 20 & 3 & 23 \\
Total & 30 & 3 & 33 \\
\hline
\end{tabular}

TABLE 3. PCNA-positive nuclei in HPV-positive and -negative cases

\begin{tabular}{lcccccc}
\hline & Negative & $\sim 25 \%$ & $26 \sim 50 \%$ & $51 \sim 75 \%$ & $76 \%$ & Total \\
\hline HPV-positive & 0 & 0 & 5 & 4 & 1 & 10 \\
HPV-negative & 3 & 4 & 7 & 7 & 2 & 23 \\
\hline
\end{tabular}

TABLE 4. Correlation between the HPV-positive and PCNA-positive nuclei within high-power fields (9 cases)

\begin{tabular}{rcccc}
\hline \multirow{2}{*}{ HPV } & \multicolumn{5}{c}{ PCNA } \\
\cline { 2 - 5 } & $\sim 25 \%$ & $26 \sim 50 \%$ & $51 \sim 75 \%$ & $76 \% \sim$ \\
\hline$\sim 25 \%$ & - & - & 1 & - \\
$26 \sim 50 \%$ & - & 2 & 1 & - \\
$51 \sim 75 \%$ & - & 5 & 4 & 3 \\
$76 \% \sim$ & - & - & 6 & 1 \\
\hline
\end{tabular}


TABLE 5. Correlation between HPV and PCNA on the nuclei of adenocarcinoma cells in the serial sections

\begin{tabular}{lcc}
\hline & PCNA positive & PCNA negative \\
\hline HPV-positive & $56 \%$ & $10 \%$ \\
HPV-negative & $18 \%$ & $16 \%$ \\
\hline
\end{tabular}

Coincidence rate $72 \% ; p<0.01$.

positive nuclei (Table 4).

Serial sections were made to compare the $1: 1$ correlation between HPV and PCNA on the nuclei of the cells identified as HPV- and PCNA-positive by careful morphologic observation. The coincidence rate was $72 \%$ (Table 5 ).

\section{Discusston}

Tase et al. (1988a, b) reported that a large percentage of uterine cervical adenocarcinoma contained HPV 18 DNA, whereas HPV 16 DNA is the most frequent type of HPV found in uterine cervical squamous cell carcinoma by in situ hybridization using a ${ }^{3} \mathrm{H}$-labeled HPV DNA probe. Walker et al. also reported that HPV 18 was mainly detected in adenocarcinoma (Walker et al. 1989). However, Griffin et al. recently reported a low frequency of HPV DNA in both adenocarcinoma and adenocarcinoma in situ employing polymerase chain reaction and in situ hybridization (Griffin et al. 1991). In our study of 39 cases of uterine cervical glandular lesions, the detection rate of HPV DNA was not as high as that previously reported (Tase et al. 1988a, b; Fransworth et al. 1989). However, among the cases positive for HPV DNA, the number of HPV 18-positive cases was higher than that of HPV 16, which is consistent with the report of Tase et al. (1988a, b).

The lower frequency of HPV infection observed in our study may be due to the use of non-RI probes in in situ hybridization. A few copies of viral genomes per cell should have been detected with in situ hybridization using ${ }^{3} \mathrm{H}$-labeled probes (Tase et al. 1989). According to the results of our study in cultured cells, ViraType in situ was thought to be about 10-fold less sensitive than in situ hybridization using ${ }^{3} \mathrm{H}$-probes.

It has generally been reported that digoxigenin-labeled probes are more sensitive than biotinylated probes in dot blotting and in situ hybridization (Morris et al. 1990). We detected HPV DNA by the digoxigenin method in 5 cases that were negative by ViraType in situ, which is consistent with the findings of the above-mentioned report. Therefore, the digoxigenin method was considered to be much more sensitive than the biotin-labeled probes among the non-RI DNA probes. Although we did not compare the sensitivity of the digoxigenin method with that of the RI-probes, several studies have shown that the sensitivity of the digoxigenin method was almost as same as that of ${ }^{35} \mathrm{~S}$-labeled probes (Heino 
et al. 1989; Furuta et al. 1990).

The reports of in vitro integration of HPV 16 and 18 DNA into cultured humam cervical cells (Woodworth et al. 1988; Waggoner et al. 1990) suggest that HPVs definitely play a role in the oncogenesis of cervical cancer. However, their role in oncogenesis, especially the proliferative activity of HPV-infected cells, has not been established. In situ hybridization of HPV cannot demonstrate whether the cells are in the proliferative stage. In order to correlate HPV infection with cell proliferation, we performed immunostaining of PCNA in adjacent tissue sections.

Anti-PCNA antibody was originally discovered as an antinuclear antibody detected in the serum of an SLE patient (Miyachi et al. 1978). This antibody reacts with proliferating cultured cells and lymphocytes activated by mitogen (Takasaki et al. 1981). This antigen shows striking accumulation in the nucleoplasm in the G1 phase, and reaches a maximum in the nucleolus in the $\mathrm{S}$ phase (Takasaki et al. 1981). This protein was termed as PCNA. By comparing flowcytometry and the image analyzing of immunohistochemistry, PCNA-positive cells have been demonstrated to correlate well with cells in the $\mathrm{S}$ phase fraction (Dawson et al. 1990).

It has been demonstrated that the rate of PCNA-positive nuclei is higher in lesions with high mitotic activity (Robbins et al. 1987). In our experiments, PCNA was detected in 30 of 33 cases of cervical adenocarcinoma and adenocarcinoma in situ. In comparing the results of in situ hybridization with those of PCNA immunostaining, all of the HPV-positive cases had a higher PCNA labeling index. On the other hand, seven of $23 \mathrm{HPV}$-negative cases showed a relatively lower rate of PCNA-positive nuclei (less than 25\%). There was a good correlation between the positive rates of HPV and PCNA in high-power fields in $9 \mathrm{HPV}$-positive cases (Table 4). Every effort was made to identify the same cells on the serial sections, but all of the cells identified as the same may not have been in our study. However, the relatively high coincidence rate $(72 \%)$ of HPV and PCNA positivity observed in the serial sections indicates a close correlation between the presence of HPV DNA and cell proliferation. Our results suggest that HPV-positive cells are active in cell proliferation, at least in human cervical adenocarcinoma.

Further investigations are needed to clarify more precise roles of HPV in cell proliferation, including possible interactions with p53 (Werness et al. 1987), a tumor suppression gene, and ultimately in oncogenesis in human uterine cervical adenocarcinoma.

\section{References}

1) Banks, L., Barnett, S.C. \& Crook, T. (1990) HPV-16 E7 functions at the $\mathrm{G}_{1}$ to $\mathrm{S}$ phase transition in the cell cycle. Oncogene, 5, 833-837.

2) Chilvers, C., Mant, D. \& Pike, M.C. (1987) Cervical adenocarcinoma and oral contra- 
ceptive. Br. Med. J., 295, 1446-1447.

3) Dawson, A.E., Norton, J.A. \& Weinberg, D.S. (1990) Comparative assessment of proliferation and DNA content in breast carcinoma by image analysis and flowcytometry. Am. J. Pathol., 136, 1115-1124.

4) Farnsworth, A., Laverty, C. \& Stoler, M.H. (1989) Human papillomavirus messenger RNA expression in adenocarcinoma in situ of the uterine cervix. Int. J. Gynecol. Pathol., 8, 321-330.

5) Furuta, Y., Shinohara, K., Meguro, M. \& Nagashima, K. (1990) In situ hybridization with digoxigenin-labelled DNA probes for detection of viral genomes. J. Clin. Pathol., 43, 806-809.

6) Gordon, A.N., Bornstein, J., Kaufman, R.H., Estrada, R.G., Adams, E., \& AdlerStolthz, K. (1989) Human papillomavirus associated with adenocarcinoma and adenosquamous carcinoma of the cervix. Gynecol. Oncol., 35, 345-348.

7) Griffin, N.R., Docky, D., Lewis, F.A. \& Wells, M. (1991) Demonstration of low frequency of human papillomavirus DNA in cervical adenocarcinoma and adenocarcinoma in situ by the polymerase chain reaction and in situ hybridization. Int $J$. Gynecol. Pathol., 10, 36-43.

8) Heiles, H.B.J., Genersch, E., Kessler, C., Neumann, R. \& Eggers, H.J. (1988) In situ hybridization with digoxigenin-labelled DNA of human papillomavirus (HPV 16/18) in Hela and SiHa cells. Biotechniques, 6, 978-981.

9) Heino, P., Hukkanen, V. \& Arstila, P. (1989) Detection of human papillomavirus (HPV) DNA in genital biopsy specimens by in situ hybridization with digoxigeninlabeled probes. J. Virol. Methods, 26, 331-338.

10) Hughes, R.G., Neill, W.A. \& Norval, M. (1989) Papilloma virus and c-myc antigen expression in normal and neoplastic cervical epithelium. J. Clin. Pathol., 42, 46-51.

11) Mathews, M.B., Bernstein, R.M., Franza, B.R. \& Garrels, J.I. (1984) Identity of the proliferating cell nuclear antigen and cyclin. Nature, 309, 374-376.

12) Miyachi, K., Fritzler, M.J. \& Tan, E.M. (1978) Autoantibody to a nuclear antigen in proliferating cells. J. Immunol., 121, 2228-2234.

13) Morris, R.G., Arends, M.J., Bishop, P.E., Sizer, K., Duvall, E. \& Bird, C.C. (1990) Sensitivity of digoxigenin and biotin labelled probes for detection of human papillomavirus by in situ hybridization. J. Clin. Pathol., 43, 800-805.

14) Nielsen, A.L. (1990) Human papillomavirus type 16/18 in uterine cervical adenocarcinoma in situ and adenocarcinoma. Cancer, 65, 2588-2593.

15) Ostrow, R.S., Manias, D.A., Clark, B.A., Okagaki, T., Twiggs, L.B. \& Faras, A.J. (1987) Detection of human papilloma DNA in invasive carcinoma of the cervix by in situ hybridization. Cancer Res., 47, 649-653.

16) Reid, R., Stanhope, C.R., Herschman, B.R., Booth, E., Phibbs, G.D. \& Smith, J.P. (1982) Genital warts and cervical cancer I. Evidence of an association between subclinical papilloma virus infection and cervical malignancy. Cancer, 50, 377-387.

17) Robbins, B.A., de la Vega, D., Ogata, K., Tan, E.M. \& Nakamura, R.M. (1987) Immunohistochemical detection of proliferating cell nuclear antigen in solid human malignancies. Arch. Pathol. Lab. Med., 111, 841-845.

18) Takasaki, Y., Deng, J.S. \& Tan, E.M. (1981) A nuclear antigen associated with cell proliferation and blast transformation. J. Exp. Med., 54, 1899-1909.

19) Tase, T., Sato, S., Wada, Y., Yajima, A. \& Okagaki, T. (1988a) Prevalence of human papillomavirus type 18 in adenocarcinoma and adenosquamous carcinoma of the uterine cervix occurring in Japan. Tohoku J. Exp. Med., 156, 47-53.

20) Tase, T., Okagaki, T., Clark, B.A., Manias, R.S., Ostrow, R.S., Twiggs, L.B. \& Faras, A.J. (1988b) Human papillomavirus types and localization in adenocarcinoma and adenosquamous carcinoma of the uterine cervix: A study by in situ hybridization. Cancer Res., 48, 993-998.

21) Tase, T., Okagaki, T., Clark, B.A., Twiggs, L.B., Ostrow, R.S. \& Faras, A.J. (1989) 
Human papillomavirus DNA in adenocarcinoma in situ, microinvasive adenocarcinoma of the uterine cervix, and coexisting cervical squamous intraepithelial neoplasia. Int. J. Gynecol. Pathol., 8, 8-17.

22) Tourtellotte, W.W., Verity, A.N., Schmid, P., Martinez, S. \& Shapshak, P. (1987) Covalent binding of formalin fixed paraffin embedded brain tissue sections to glass slides suitable for in situ hybridization. J. Virol. Methods., 15, 87-99.

23) Waggoner, S.E., Woodworth, C.D., Stoler, M.H., Barnes, W.A., Delgado, G. \& DiPaolo, J.A. (1990) Human cervical cells immortalized in vitro with oncogenic human papillomavirus DNA differentiate dysplastically in vivo. Gynecol. Oncol., 38, 407412.

24) Walker, J., Bloss, J.D., Liao, S.Y., Berman, M., Bergen, S. \& Wilczynski, S.P. (1989) Human papillomavirus genotype as a prognostic indicator in carcinoma of the uterine cervix. Obstet. Gynecol., 74, 781-785.

25) Werness, B.A., Levine, A.J. \& Howley, P.M. (1990) Association of human papillomavirus type 16 and $18 \mathrm{E} 6$ protein with p53. Science, 24, 76-79.

26) Woodworth, C.D., Bowden, P.E., Doniger, J., Pirisi, W., Barnes, W., Lancaster, W.D. \& DiPaolo, J.A. (1988) Characterization of normal exocervical epithelial cells immortalized in vitro by papillomavirus types 16 and 18 DNA. Cancer Res., 48, 46204628.

27) Yoshikawa, H., Matsukura, T., Yamamoto, E., Kawana, T., Mizuno, M. \& Yoshike, K. (1985) Occurrence of human papillomavirus type 16 and 18 DNA in cervical carcinoma from Japan: Age and histological type of carcinoma. Jpn. J. Cancer Res. (Gann), 76, 667-671. 